\title{
TINGKAT KESEHATAN KEUANGAN ORGANISASI PENGELOLA ZAKAT DI INDONESIA
}

Siti Aminah Anwar ${ }^{\bowtie}$, Anik Malikah

Universitas Islam Malang, Indonesia

sitiaminahanwar_fe@unisma.ac.id, anikmalikah_fe@unisma.ac.id

https://doi.org/10.46367/jas.v5i2.434

Received: Nov 19, 2021 Revised: Dec 06, 2021 Accepted: Dec 14, 2021 Published: Dec 21, 2021

\begin{abstract}
As the largest Muslim country in the world, Indonesia has great potential in collecting zakat, infaq, alms, and waqf funds (ZISWAF) to alleviate poverty and social inequality. This study aims to demonstrate the financial health or performance of the zakat management organization (ZMO) by analyzing the ratio of activity, efficiency, amil, liquidity, and growth based on the provisions of the strategic study centre the national amil zakat agency (Puskasbaznas). This study uses a sample of twenty financial statements from five ZMO published from 20152018. This study uses an explanatory research method with a quantitative descriptive approach. The results show that the financial statements of the ZMO have implemented PSAK 45 and PSAK 109. The financial health or performance of the ZMO is categorized as quite reasonable. Then the efficiency ratio affects the financial health or performance of ZMO. In contrast, the ratio of activity, amil, liquidity, and growth do not affect the financial health or performance of ZMO. The results of this study are able to detect ZMO who do not aim to make a profit. Then it is used as a reference for ZMO in improving financial health or organizational performance.
\end{abstract}

Keywords: Puskasbaznas Ratio, Financial Health, PSAK 45, PSAK 109, Zakat Management Organization.

\begin{abstract}
ABSTRAK
Indonesia sebagai negara Muslim terbesar di dunia menjadi potensi yang besar dalam menghimpun dana zakat, infaq, sedekah dan wakaf (ZISWAF) untuk mengentaskan kemiskinan dan kesenjangan sosial. Tujuan penelitian ini adalah untuk menunjukkan kesehatan keuangan atau kinerja organisasi pengelola zakat (OPZ) dengan menganalisis rasio aktivitas, efisiensi, dana amil, likuiditas, dan pertumbuhan berdasarkan ketentuan pusat kajian strategis badan amil zakat nasional (Puskasbaznas). Penelitian ini menggunakan sampel dua puluh laporan keuangan dari lima OPZ yang dipublikasikan mulai tahun 2015-2018. Penelitian ini menggunakan metode explanatory research dengan pendekatan deskriptif kuantitatif. Hasil penelitian menunjukkan bahwa laporan keuangan OPZ telah menerapkan PSAK 45 dan PSAK 109. Kesehatan keuangan atau kinerja OPZ masuk kategori penilaian cukup baik. Kemudian rasio efisiensi berpengaruh terhadap kesehatan keuangan atau kinerja OPZ. Sedangkan rasio aktivitas, amil, likuiditas dan pertumbuhan tidak berpengaruh terhadap kesehatan keuangan atau kinerja OPZ. Hasil penelitian ini mampu mendeteksi OPZ yang tidak bertujuan
\end{abstract}


untuk mendapatkan keuntungan. Kemudian digunakan sebagai referensi bagi OPZ dalam meningkatkan kesehatan keuangan atau kinerja organisasi.

Kata Kunci: Rasio Puskasbaznas, Kesehatan Keuangan, PSAK 45, PSAK 109, Organisasi Pengelola Zakat.

\section{PENDAHULUAN}

Seorang Muslim harus sadar akan kewajibannya dalam menjalankan perintah Allah SWT. tanpa terkecuali salah satunya yaitu zakat. Kewajiban membayar zakat merupakan ibadah yang bertujuan membersihkan harta selama satu tahun ketika sudah mencapai nishabnya. Berdasarkan data statistik, Indonesia merupakan penganut agama Islam terbesar di seluruh dunia. Hal ini bisa menjadi potensi besar dalam menghimpun dana untuk kemudian hari bisa dimanfaatkan dan dikelola dengan profesional, sehingga bisa mengentaskan kemiskinan dan kesenjangan sosial. Untuk mencapai hal tersebut perlu adanya transparansi dan profesionalisme dalam organisasi pengelola zakat (OPZ) yang tercermin pada kinerja atau kesehatan keuangan. OPZ merupakan organisasi nirlaba yang konsentrasinya bukan mengejar keuntungan. Meskipun demikian organisasi nirlaba harus memiliki manajemen keuangan yang baik mencakup pengelolaan keuangan, kecukupan dana untuk menjalankan aktivitas sosial berkelanjutan (CPAA 2014).

OPZ sebagai organisasi nirlaba dituntut harus bertanggung jawab dalam pengelolaan keuangan, dalam hal ini berupa laporan keuangan yang bertujuan untuk menilai kinerja organisasi nirlaba. Hal tersebut sesuai dengan aturan baku IAI dalam PSAK 45 yang mengatur bahwa organisasi nirlaba diharapkan membuat laporan keuangan secara relevan (IAI 2010). Kemudian PSAK 109 berisi tentang akuntansi zakat, infak dan sedekah (IAI 2008). Berdasar hal tersebut OPZ dituntut menyajikan laporan keuangan yang jelas, tidak ada yang ditutup-tutupi dan dapat dipertanggungjawabkan seperti yang diatur dalam peraturan badan amil zakat nasional (BAZNAS) Republik Indonesia nomor 5 tahun 2018 tentang pengelolaan keuangan zakat (Puskasbaznas 2019).

Evaluasi keuangan OPZ ada yang menggunakan pendekatan data envelopment analysis (DEA) (Parisi 2017). Selain itu kinerja OPZ dapat dievaluasi dengan menggunakan international standard of zakah management (ISZM) yang terdiri dari penilaian efisiensi dan kapasitas OPZ (Harto, Anggraeni, and Bayinah 2018). Terdapat anggapan bahwa mengelola dana sumbangan bisa semaunya tanpa ada acuan penilaian kinerja operasional atau kesehatan keuangan, sehingga beberapa penelitian memberikan hasil penelitian kinerja/kesehatan keuangan OPZ yang tidak baik. Penelitian yang dilakukan oleh Anwar, Itang, and Risyanto (2019) mengungkapkan bahwa dari 5 OPZ yang diteliti belum optimal dalam memanfaatkan sumber daya yang ada secara ekonomis dan belum efisien dalam mengelola output. Kemudian penelitian Prayogi (2019) menemukan bahwa kinerja BAZNAS kota Tangerang Selatan dengan pendekatan indeks zakat nasional tertuju pada pemerintah dan masyarakat berada pada kondisi tidak baik, sedangkan nilai indeks tertuju pada mustahik berada pada kondisi baik. Penelitian Lubis and Budiman (2018) mengungkapkan bahwa BAZNAS Yogyakarta memiliki kinerja dinilai cukup baik dalam pengelolaannya. Tetapi dalam 
penelitian Lestari (2015) BAZDA di Lombok Timur bisa mencapai rasio efisiensi yang ditentukan selama tiga periode. Sedangkan dalam penelitian Ainun, Handayani, and Fahmi (2020) menunjukkan bahwa rasio aktivitas OPZ menggambarkan kinerja amil yang baik.

Berdasarkan hasil penelitian tersebut, maka penelitian ini memiliki kebaruan yaitu mengkaji kinerja/kesehatan keuangan OPZ menggunakan rasio aktivitas, efisiensi, amil, likuiditas dan pertumbuhan. Kriteria penilaian kinerja atau kesehatan keuangan OPZ mengacu kepada rasio yang dikeluarkan Puskasbaznas. Akan tetapi penelitian yang lain menggunakan rasio bukan berasal dari rasio dari Puskasbaznas. Kemudian pengukuran kinerja menggunakan indeks zakat nasional (IZN) atau DEA. Oleh sebab itu penelitian ini bertujuan untuk menjustifikasi penyajian laporan keuangan OPZ apakah sudah sesuai dengan PSAK 45 dan PSAK 109. Kemudian untuk menunjukkan kesehatan atau kinerja keuangan OPZ. Selanjutnya untuk menunjukkan faktor yang mempengaruhi kesehatan atau kinerja keuangan OPZ ditinjau dari aspek rasio keuangan Puskasbaznas.

\section{TELAAH LITERATUR}

\section{Zakat}

Lafaz zakat bisa diartikan tumbuhan dan berkembang. Zakat menurut syara' bisa diartikan sejumlah harta yang diberikan kepada golongan dengan syarat tertentu. Jadi maksudnya kekayaan akan tumbuh dan bertambah dikarenakan berkah karena dikeluarkan zakatnya dan ada do'a dari si penerima zakatnya (Abubakar 1993). Landasan hukum diwajibkannya pembayaran zakat terhadap orang Muslim terdapat dalam Al-Quran surat At-Taubah ayat 103:

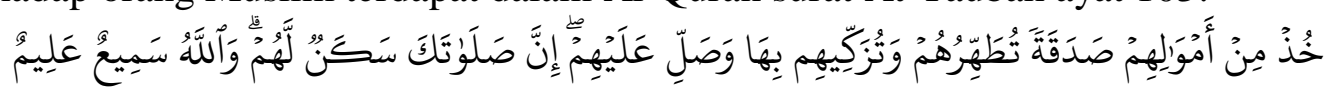

Artinya: "Ambillah zakat dari sebagian harta mereka, dengan zakat itu kamu membersihkan dan mensucikan mereka, dan berdoalah untuk mereka. Sesungguhnya doamu itu (menumbuhkan) ketentraman jiwa bagi mereka, Allah maha mendengar, maha mengetahui."

Pembayaran zakat termasuk katagori ibadah sehingga hukum membayar zakat adalah wajib atas laki-laki dan perempuan Muslim. Ada beberapa jenis zakat yaitu: zakat nafs (jiwa) atau zakat fitrah dan zakat maal (harta) (Kemenag RI 2011).

\section{Kinerja/Kesehatan Keuangan Organisasi Pengelola Zakat (OPZ)}

Akuntansi merupakan sistem informasi yang disajikan secara akurat dan relevan dalam rangka pengambilan keputusan. Menurut PSAK 45 tentang pelaporan entitas nirlaba dan PSAK 109 tentang akuntansi zakat dan infaq/sedekah. Pembuatan laporan keuangan OPZ sebagai bentuk pertanggung jawaban keuangan. Laporan keuangan yang harus disediakan OPZ terdiri dari: laporan posisi keuangan, laporan perubahan dana, laporan perubahan aset kelolaan, laporan arus kas dan catatan atas laporan keuangan (IAI 2008; 2010).

Analisis rasio keuangan dilakukan untuk membandingkan kinerja OPZ. Kinerja keuangan yang tergambarkan dari hasil hitung rasio keuangan mencerminkan kepatuhan lembaga zakat terhadap kaidah atau aturan-aturan syariah (Puskasbaznas 2019). Kinerja keuangan disajikan sebagai bentuk 
pertanggung jawaban kelolaan dana yang dilakukan sudah efisien dalam menjalankan program OPZ dalam pengelolaan dana umat dan otomatis akan menimbulkan kepercayaan para muzaki/donatur/penyumbang untuk membayar zakat pada lembaga zakat yang bersangkutan. Analisis kesehatan keuangan OPZ diproksikan dengan rasio aktivitas, efisiensi, dana amil, likuiditas dan pertumbuhan (Puskasbaznas 2019).

Rasio aktivitas digunakan untuk mengukur aktivitas operasional dana zakat, infak dan sedekah yang dihimpun oleh OPZ beserta penyalurannya dalam satu tahun yang bersangkutan. Rasio Efisiensi digunakan untuk mengukur efisiensi atas biaya-biaya operasional yang dikeluarkan oleh OPZ dalam kegiatan penghimpunan dan penyaluran dana zakat, infak dan sedekah. Semakin efisien OPZ dalam melakukan penghimpunan semakin baik tata kelola lembaga zakat tersebut. Rasio dana amil digunakan untuk mengukur efektivitas penggunaan dana amil dalam kegiatan penghimpunan dan penyaluran dana zakat, infak dan sedekah (Puskasbaznas 2019).

Rasio likuiditas digunakan untuk mengukur kemampuan OPZ untuk melunasi kewajiban jangka pendek. Pengukuran rasio likuiditas ini difungsikan untuk mengetahui dana yang mengendap yang belum tersalurkan, dan juga untuk mengetahui kemampuan OPZ dalam menyalurkan dana zakat, infak dan sedekah kepada yang berhak menerima. Rasio pertumbuhan merupakan rasio yang menggambarkan pertumbuhan penghimpunan dan penyaluran dana zakat, infaq, dan sedekah pada OPZ dari tahun-tahun sebelumnya (Puskasbaznas 2019).

\section{Pengembangan Hipotesis}

Kesehatan atau kinerja laporan keuangan OPZ ditentukan dari rasio aktivitas, efisiensi, amil, likuiditas, pertumbuhan. Pengukuran kriteria penilaian rasio baik sekali, baik, cukup baik, dan tidak baik ditentukan oleh Puskasbaznas. . Penelitian yang dilakukan oleh Lubis and Budiman (2018) menyatakan bahwa BAZNAS Yogyakarta memiliki kinerja cukup baik dalam pengelolaannya, sehingga dapat dirumuskan hipotesis pertama $\left(\mathrm{H}_{1}\right)$ : laporan keuangan $\mathrm{OPZ}$ menunjukkan kesehatan/kinerja cukup baik.

Penelitian relevan mengenai rasio yang dikeluarkan oleh Puskasbaznas terhadap kesehatan atau kinerja keuangan OPZ belum ditemukan. Oleh sebab itu berdasarkan ukuran penilaian yang sudah dapat dirumuskan hipotesis sebagai berikut:

$\mathrm{H}_{2}$ : Ada pengaruh rasio aktivitas terhadap kesehatan atau kinerja keuangan OPZ.

$\mathrm{H}_{3}$ : Ada pengaruh rasio efisiensi terhadap kesehatan atau kinerja keuangan OPZ.

$\mathrm{H}_{4}$ : Ada pengaruh rasio dana amil terhadap kesehatan atau kinerja keuangan OPZ.

$\mathrm{H}_{5}$ : Ada pengaruh rasio likuiditas terhadap kesehatan atau kinerja keuangan OPZ.

$\mathrm{H}_{6}$ : Ada pengaruh rasio pertumbuhan terhadap kesehatan atau kinerja keuangan OPZ.

\section{METODE PENELITIAN}

Penelitian ini menggunakan metode explanatory research dengan pendekatan deskriptif kuantitatif. Explanatory research yaitu penelitian yang ditujukan untuk menganalisa hubungan dan pengaruh satu variabel dengan variabel lainnya (Umar 2014). Populasi penelitian ini adalah seluruh OPZ yang 
ada di Indonesia periode 2015-2018 (Baznas 2019). Teknik yang dipakai dalam mengambil sampel adalah purposive sampling dimana pengambilan subyek yang kita pilih bukan berdasar golongan, acak atau wilayah tetapi berdasarkan tujuan atau kriteria yang dibuat (Arikunto 2013). Kriteria sampel yang digunakan adalah: (1) OPZ yang ada di Indonesia. (2) OPZ yang mempublikasi laporan keuangan secara konsisten periode 2015-2018. Berdasarkan kriteria tersebut di dapat 5 dari 20 OPZ yaitu: BAZNAS, Rumah Zakat Indonesia, Lembaga Amil Zakat (LAZ) Yayasan Yatim Mandiri, LAZ Al Azhar, Baitul Mal Umat Islam Bank Negara Indonesia (Bamus BNI).

Pengumpulan data berupa laporan keuangan OPZ dengan memakai metode dokumentasi, selanjutnya data tersebut diklasifikasikan lalu langkah selanjutnya adalah dilakukan pengolahan data. Pengolahan data dan dilanjutkan analisis data untuk uji hubungan variabel bebas dan terikat memakai model analisis pendekatan deskriptif untuk menjawab analisis regresi linear berganda dengan menggunakan SPSS (Aldi 2016). Analisis kinerja atau kesehatan keuangan OPZ diproksikan dan pengukuran interpretasi penilaian rasio (Puskasbaznas 2019).

Tabel 1. Ukuran Interpretasi Penilaian Rasio Aktivitas
\begin{tabular}{ccc} 
No. & Hasil & Kriteria \\
\hline 1 & Rasio $<45 \%$ & Tidak Efektif \\
2 & $45 \% \leq$ Rasio $<60 \%$ & Kurang Efektif \\
3 & $60 \% \leq$ Rasio $<75 \%$ & Cukup Efektif \\
4 & $75 \% \leq$ Rasio $\leq 90 \%$ & Efektif \\
5 & Rasio $>90 \%$ & Sangat Efektif \\
\hline Sumber: (puskasbaznas 2019) &
\end{tabular}

Tabel 2. Ukuran Interpretasi Penilaian Rasio Efisiensi

\begin{tabular}{clc}
\hline No. & \multicolumn{1}{c}{ Hasil } & Kriteria \\
\hline 1 & Rasio $<2 \%$ & Efisien \\
2 & $2 \% \leq$ Rasio $\leq 5 \%$ & Cukup Efisien \\
3 & Rasio $>5 \%$ & Tidak Efisien \\
\hline Sumber: & (puskasbaznas 2019)
\end{tabular}

Tabel 3. Ukuran Interpretasi Penilaian Rasio Dana Amil

\begin{tabular}{ccc}
\hline No. & \multicolumn{1}{c}{ Hasil } & Kriteria \\
\hline 1 & Rasio $\leq 12,5 \%$ & Baik \\
2 & Rasio $>12,5 \%$ & Tidak Baik \\
\hline Sumber: & (puskasbaznas 2019)
\end{tabular}

Tabel 4. Ukuran Interpretasi Penilaian Rasio Likuiditas

\begin{tabular}{ccl}
\hline No & \multicolumn{1}{c}{ Hasil } & \multicolumn{1}{c}{ Kriteria } \\
\hline 1 & Rasio $<1$ & $\begin{array}{l}\text { Tidak baik, karena aktiva lancar tidak dapat } \\
\text { membayar kewajiban jangka pendeknya di periode } \\
\text { yang bersangkutan } \\
\text { Baik, karena aktiva lancar dapat membayar kewajiban }\end{array}$ \\
2 & $1<$ Rasio $\leq 1,5$ & $\begin{array}{l}\text { jangka pendeknya di periode yang bersangkutan. } \\
\text { Tidak baik, karena adanya dana mengendap belum } \\
\text { tersalurkan. }\end{array}$ \\
3 & Rasio $>1,5$ &
\end{tabular}


Tabel 5. Ukuran Interpretasi Penilaian Rasio Pertumbuhan

\begin{tabular}{clc}
\hline No. & \multicolumn{1}{c}{ Hasil } & Kriteria \\
\hline 1 & Rasio $>130 \%$ & Baik Sekali \\
2 & $120 \%<$ Rasio $\leq 130 \%$ & Baik \\
3 & $100 \%<$ Rasio $\leq 120 \%$ & Cukup Baik \\
4 & Rasio $\leq 100 \%$ & Tidak Baik \\
\hline Sumber: (puskasbaznas 2019) &
\end{tabular}

\section{HASIL DAN PEMBAHASAN PENELITIAN}

\section{Deskriptif Penelitian}

\section{Gambar 1. Interpretasi Penilaian Rasio Aktivitas}

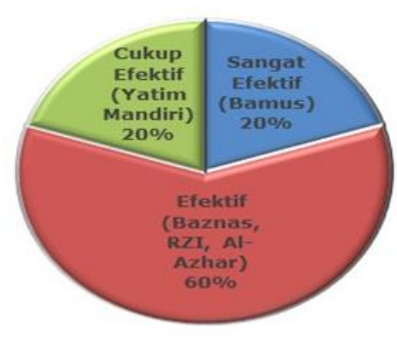

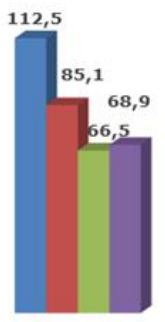

Baznas

Baznas

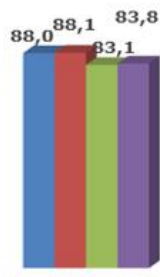

Rumah Zakat Indonesia

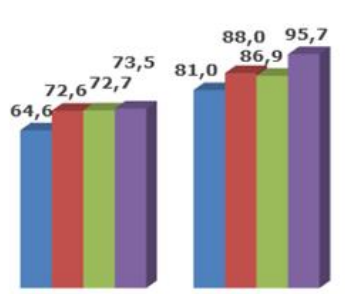

LAZ YYS LAZ Al Azhar Matim 2015

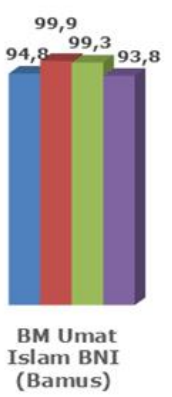

Sumber: data sekunder (diolah)

Berdasarkan Gambar 1, OPZ yang sudah melakukan penyaluran dana organisasi secara sangat efektif yaitu Baitul Maal Umat Islam BNI (Bamus BNI). Kemudian OPZ yang sudah melakukan penyaluran dana organisasi secara efektif yaitu BAZNAS, Rumah Zakat Indonesia dan Al Azhar. Sedangkan OPZ yang melakukan penyaluran dana organisasi secara cukup efektif yaitu Yayasan Yatim Mandiri.

\section{Gambar 2. Interpretasi Penilaian Rasio Efisiensi}

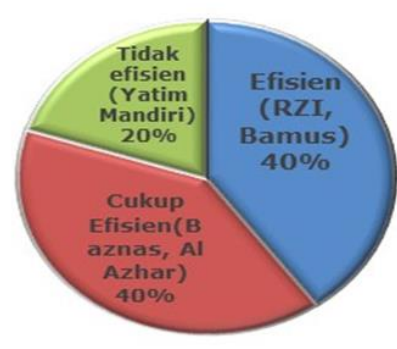

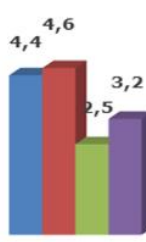

Baznas

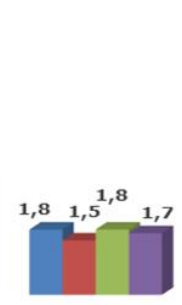

Rumah Zakat Indonesia

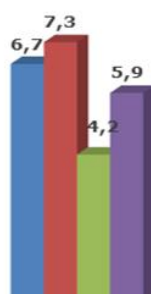

LAZ YYS Matim

" $2018=2017=2016=2015$

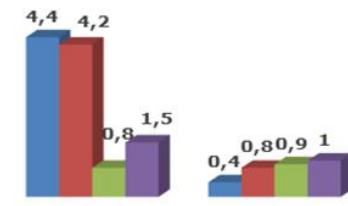

LAZ Al AZhar

BM Umat Islam BNI
(Bamus)

Sumber: data sekunder (diolah)

Berdasarkan Gambar 2, OPZ yang sudah melakukan efisiensi biaya yang dikeluarkan untuk menghimpun dana zakat secara sangat efisien adalah Rumah 
Zakat Indonesia dan Baitul Maal Umat Islam BNI (Bamus BNI). Kemudian efesiensi secara cukup efisien dilakukan oleh BAZNAS dan Al Azhar. Sedangkan OPZ yang melakukan efisiensi secara tidak efisien adalah Yayasan Yatim Mandiri.

\section{Gambar 3. Interpretasi Penilaian Rasio Dana Amil}
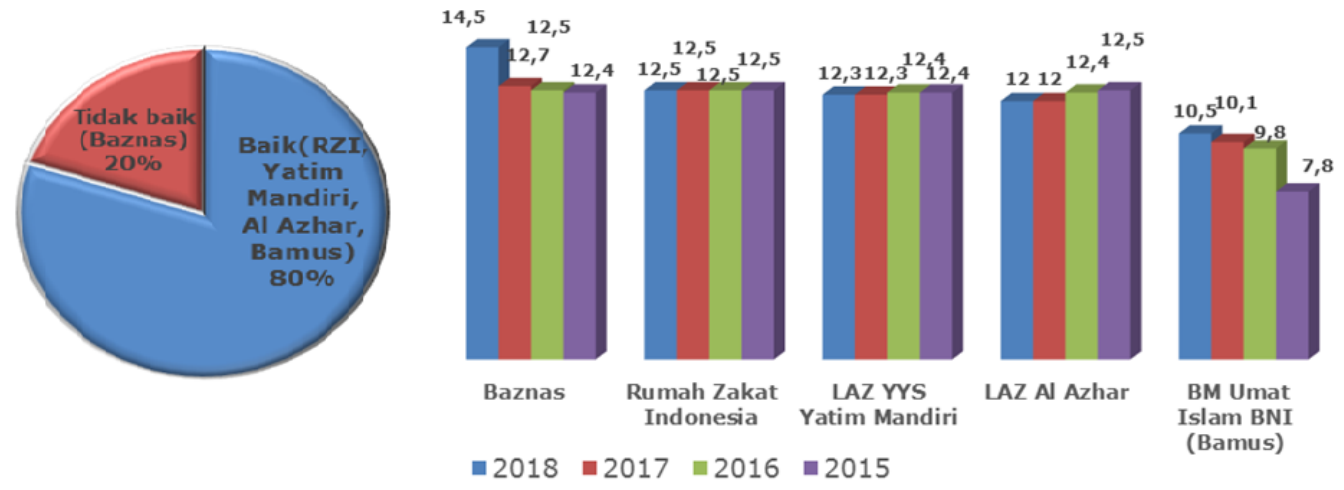

Sumber: data sekunder (diolah)

Berdasarkan Gambar 3, OPZ Rumah Zakat Indonesia, Yayasan Yatim Mandiri, Al Azhar, dan Bamus BNI menunjukkan mampu melakukan efektivitas dan efisiensi dana amil untuk operasional menghimpun dan menyalurkan yang dilakukan dengan Baik. Sedangkan BAZNAS dalam mengoperasionalkan dana amil menunjukkan tidak baik.

\section{Gambar 4. Interpretasi Penilaian Rasio Likuiditas}
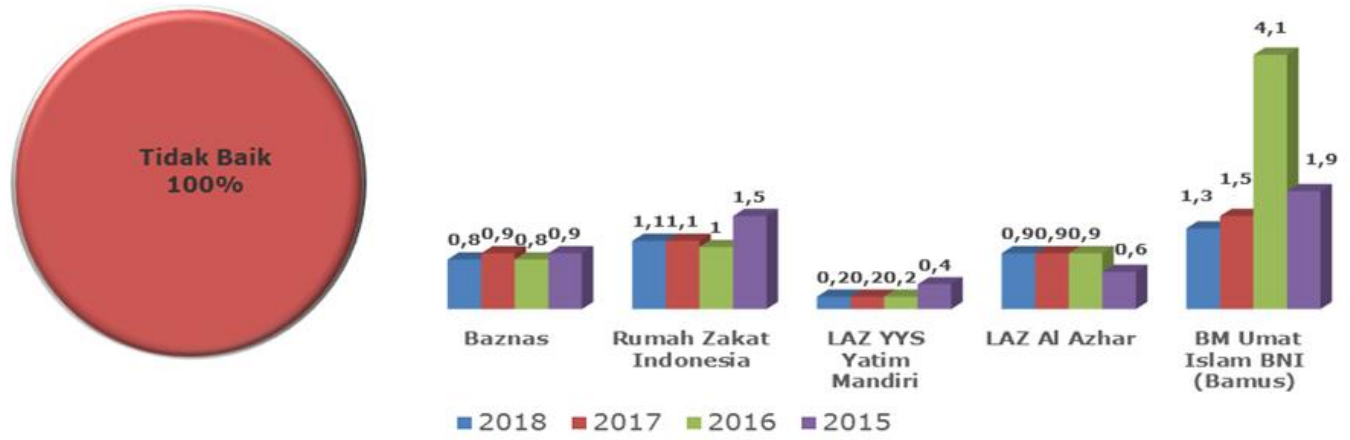

Sumber: data sekunder (diolah)

Berdasarkan Gambar 4, interpretasi penilaian rasio likuiditas lima OPZ menunjukkan penilaian tidak baik, maksudnya disini bahwa OPZ BAZNAZ, Yayasan Yatim Mandiri, dan Al Azhar aset lancarnya tidak mampu membayar hutang jangka pendeknya termasuk dana yang belum terealisasi atau belum dikeluarkan untuk disalurkan yaitu dana zakat, infak dan sedekah (ZIS) pada satu periode. Sedangkan OPZ Rumah Zakat Indonesia dan Bamus BNI ada indikasi pengendapan dana dalam bentuk piutang dana, maksudnya ada dana yang belum terealisasi atau belum dikeluarkan untuk disalurkan. 


\section{Gambar 5. Interpretasi Penilaian Rasio Pertumbuhan}

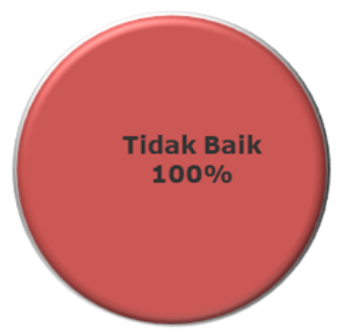

Baznas

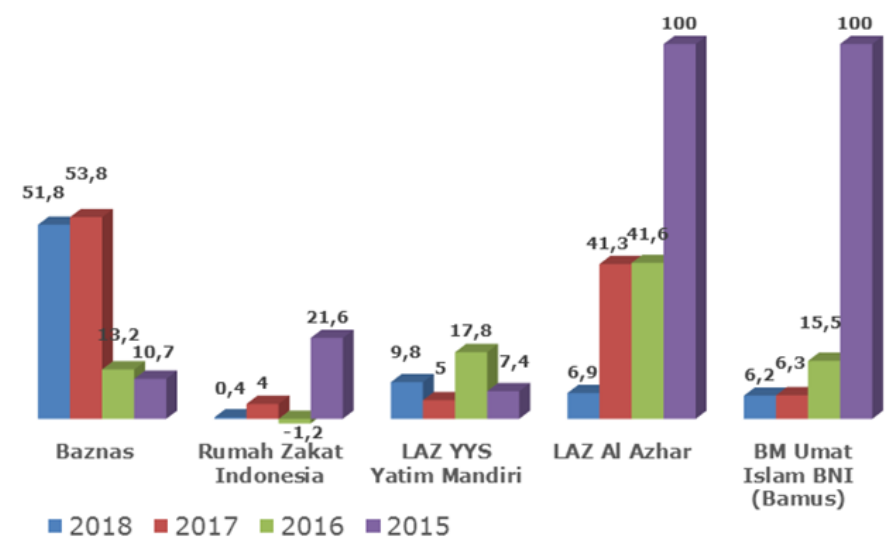

Sumber: data sekunder (diolah)

Berdasarkan Gambar 5, interpretasi penilaian rasio pertumbuhan lima OPZ menunjukkan tidak baik, maksudnya dari kelima OPZ memiliki rasio rata-rata dibawah 100 persen.

Tabel 6. Rasio Kinerja/Kesehatan Keuangan

\begin{tabular}{|c|c|c|c|c|c|c|}
\hline Nama & Aktivitas & Efisiensi & $\begin{array}{l}\text { Dana } \\
\text { Amil }\end{array}$ & Likuiditas & Pertumbuhan & Kinerja \\
\hline $\begin{array}{l}\text { BAZNAS (Baznas } \\
\text { 2019) }\end{array}$ & 83,2 & 3,67 & 13 & 0,84 & 3,24 & 1,8 \\
\hline $\begin{array}{l}\text { Rumah Zakat } \\
\text { Indonesia (RZI } \\
\text { 2020) } \\
\text { LAZ Yayasan }\end{array}$ & 85,7 & 1,69 & 12,5 & 1,17 & 6,2 & 2,4 \\
\hline (YYM 2020) & 70,8 & 6 & 12,4 & 0,25 & 10 & 1,7 \\
\hline $\begin{array}{l}\text { LAZ Al Azhar (Al } \\
\text { Azhar 2020) } \\
\text { BM Umat Islam }\end{array}$ & 87,9 & 2,73 & 12,2 & 0,83 & 47,5 & 2,2 \\
\hline $\begin{array}{l}\text { BNI (Bamus BNI } \\
\text { 2020) }\end{array}$ & 96,9 & 0,8 & 9,58 & 2,22 & 32 & 2,7 \\
\hline
\end{tabular}

Sumber: data sekunder (diolah)

Nilai rasio aktivitas, efisiensi, amil, likuiditas, dan pertumbuhan dari lima OPZ dikatagorikan kedalam masing-masing kriteria penilaian yang dikeluarkan Puskasbaznas. Selanjutnya skala penilaian diberi skor (Tidak Baik = Skor 1), $($ Cukup Baik $=$ Skor 2), $($ Baik Skor $=3)$, dan $($ Sangat Baik Skor $=4)$. Berdasarkan Tabel 6, dapat dilihat bahwa 20 laporan keuangan dari lima OPZ menunjukkan kesehatan/kinerja keuangan OPZ belum masuk kategori baik, karena nilai ratarata kinerja kelima OPZ sebesar 2,1, sehingga dapat dikategorikan dalam penilaian cukup baik.

\section{Uji Normalitas}

Uji statistik yang digunakan untuk menguji normalitas residual dalam penelitian ini dengan pengujian one-sample kolmogorof-smirnov test (uji K-S). 
Uji K-S merupakan uji normalitas secara non parametik terhadap masing-masing variabel, dengan ketetapan keputusan, jika nilai asymp sig. (2-tailed) > 0,05 maka data memiliki distribusi normal dan sebaliknya data tidak berdistribusi normal. Berdasarkan Tabel 8, diketahui bahwa nilai asymp sig. (2-tailed) data aktivitas memiliki nilai sebesar 0,938, efisiensi sebesar 0,342, dana amil sebesar 0,051, likuiditas sebesar 0,182, pertumbuhan sebesar 0,156, dan kinerja sebesar 0,299, dimana semua nilai asymp sig. (2-tailed) > 0,05, sehingga dapat dikatakan bahwa semua data berdistribusi normal.

Tabel 7. Hasil Uji Normalitas

\begin{tabular}{lcccccc}
\hline & Aktivitas & Efisiensi & $\begin{array}{c}\text { Dana } \\
\text { Amil }\end{array}$ & Likuiditas & Pertumbuhan & Kinerja \\
\hline$N$ & 20 & 20 & 20 & 20 & 20 & 20 \\
Kolmogorov-Smirnov $Z$ & 0,534 & 0,938 & 1,355 & 1,095 & 1,130 & 0,974 \\
Asymp. Sig. (2-tailed) & 0,938 & 0,342 & 0,051 & 0,182 & 0,156 & 0,299 \\
\hline Sur
\end{tabular}

Sumber: data sekunder (diolah)

\section{Uji Hipotesis}

Tabel 8. Hasil One Sample Test

\begin{tabular}{lccc}
\hline & $\boldsymbol{t}$ & Sig. (2-tailed) & Mean Difference \\
\hline Kinerja & 21,059 & 0,000 & 2,18000 \\
\hline Sumber: data sekunder (diolah) &
\end{tabular}

Tabel 9. Hasil Uji T

\begin{tabular}{lccc}
\hline \multicolumn{1}{c}{ Model } & $\boldsymbol{\alpha} / \boldsymbol{\beta}$ & $\boldsymbol{t}$ & Sig. \\
\hline (Constant) & 2,941 & 4,114 & 0,001 \\
Aktivitas & 0,012 & 1,912 & 0,077 \\
Efisiensi & $-0,173$ & $-5,081$ & 0,000 \\
Dana Amil & $-0,083$ & $-1,590$ & 0,134 \\
Likuiditas & $-0,144$ & $-1,458$ & 0,167 \\
Pertumbuhan & $-0,003$ & $-1,614$ & 0,129 \\
\hline \multicolumn{2}{l}{ Sumber: data sekunder (diolah) } & &
\end{tabular}

Berdasarkan Tabel 8, diketahui nilai $t_{\text {hitung }}=21,059$, sedangkan nilai $t_{\text {tabel }}=2,093$ (one sample test), dan nilai sig. 2 tailed $=0,000$. Sehingga nilai $t_{\text {hitung }}(21,059)>$ $\mathrm{t}_{\text {tabel }}(2,093)$ sign $0,00<0,05$ maka hipotesis $\mathrm{H}_{1}$ diterima, artinya laporan keuangan OPZ menunjukkan kesehatan/kinerja cukup baik. Kemudian untuk uji t diperoleh nilai $\mathrm{t}_{\text {tabel }}=\alpha / 2 ; \mathrm{n}-\mathrm{k}-1=0,05 / 2 ; 20-5-1=0,025 ; 14=2,145$. Berdasarkan Tabel 9, untuk rasio aktivitas diperoleh nilai $t_{\text {hitung }}$ sebesar 1,912 dan nilai sig. sebesar 0,077 , sehingga nilai $\mathrm{t}_{\text {hitung }}<\mathrm{t}_{\text {tabel }}(1,912<2,145)$ dan nilai sig. $>$ $0,05(0,077>0,05)$ maka $\mathrm{H}_{2}$ ditolak, artinya tidak ada pengaruh dan tidak signifikan antara rasio aktivitas terhadap kesehatan atau kinerja keuangan OPZ. Rasio efisiensi diperoleh nilai $t_{\text {hitung }}$ sebesar $-5,081$ dan nilai sig. 0,000, sehingga nilai $-\mathrm{t}_{\text {hitung }}<-\mathrm{t}_{\text {tabel }}(-5,081<-2,145)$ dan nilai sig. $<0,05(0,000<0,05)$ maka $\mathrm{H}_{3}$ diterima, artinya ada pengaruh yang signifikan antara rasio efisiensi terhadap 
kesehatan atau kinerja keuangan OPZ. Rasio dana amil diperoleh nilai $t_{\text {hitung }}$ sebesar $-1,590$ dan nilai sig. 0,134 , sehingga nilai $-t_{\text {hitung }}>-t_{\text {tabel }}(-1,590>-2,145)$

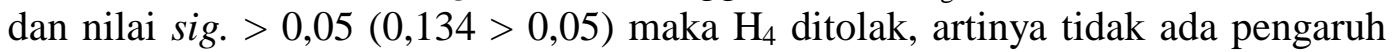
dan tidak signifikan antara rasio dana amil terhadap kesehatan atau kinerja keuangan OPZ. Rasio likuiditas diperoleh nilai $t_{\text {hitung }}$ sebesar $-1,458$ dan nilai sig. 0,167 , sehingga nilai $-t_{\text {hitung }}>-t_{\text {tabel }}(-1,458>-2,145)$ dan nilai sig. $>0,05(0,167>$ $0,05)$ maka $\mathrm{H}_{5}$ ditolak, artinya tidak ada pengaruh dan tidak signifikan antara rasio likuiditas terhadap kesehatan atau kinerja keuangan OPZ. Rasio pertumbuhan diperoleh nilai $\mathrm{t}_{\text {hitung }}$ sebesar $-1,614$ dan nilai sig. 0,129 , sehingga nilai $-\mathrm{t}_{\text {hitung }}>$ $\mathrm{t}_{\text {tabel }}(-1,614>-2,145)$ dan nilai sig. $>0,05(0,129>0,05)$ maka $_{6}$ ditolak, artinya tidak ada pengaruh dan tidak signifikan antara rasio pertumbuhan terhadap kesehatan atau kinerja keuangan OPZ.

Tabel 10. Hasil Uji F Dan Koefisien Determinasi

\begin{tabular}{lccccc}
\hline \multicolumn{1}{c}{ Model } & Sum of Squares & $\boldsymbol{d f}$ & Mean Square & $\boldsymbol{F}$ & Sig. \\
\hline Regression & 3,320 & 5 & 0,664 & 12,365 & 0,000 \\
Residual & 0,752 & 14 & 0,054 & & \\
Total & 4,072 & 19 & & & \\
\hline$R$ & & & & 0,903 & \\
$R$ Square & & & & 0,815 & \\
Adjusted R Square & & & 0,749 & \\
\hline Sumber: data sekunder (diolah) & & & &
\end{tabular}

Berdasarkan Tabel 10, diperoleh nilai $F_{\text {hitung }}$ sebesar 12,365, nilai sig. sebesar 0,000 dan nilai Adjusted $R$ Square sebesar 0,749 (74,9\%). Diketahui bahwa nilai $F_{\text {tabel }}$ sebesar 3,06, sehingga $F_{\text {hitung }}>F_{\text {tabel }}(12,365>3,06)$ dan sig. < $0,05(0,000,0,05)$, artinya terdapat pengaruh yang signifikan antara rasio aktivitas, efisiensi, amil, likuiditas, dan pertumbuhan secara simultan terhadap kesehatan atau kinerja keuangan OPZ periode 2015-2018, dengan besar pengaruhnya adalah $74,9 \%$.

\section{Kesehatan/Kinerja Keuangan Organisasi Pengelola Zakat}

Hasil penelitian ini menunjukkan bahwa hipotesis $\mathrm{H}_{1}$ diterima, artinya laporan keuangan OPZ menunjukkan kesehatan/kinerja cukup baik. Hal tersebut didukung dengan hasil rata-rata kinerja lima OPZ yang terlihat pada Tabel 6, dimana nilai rata-rata kinerja sebesar 2,1, sehingga masuk dalam katagori penilaian cukup baik. Hasil penelitian ini sejalan dengan penelitian yang dilakukan oleh Lubis and Budiman (2018) yang menyatakan bahwa BAZNAS Yogyakarta memiliki kinerja dinilai cukup baik dalam pengelolaannya. Hasil penelitian ini tidak sejalan dengan penelitian yang dilakukan oleh Prayogi (2019) yang menemukan bahwa kinerja BAZNAS kota Tangerang Selatan dengan pendekatan indeks zakat nasional tertuju pada pemerintah dan masyarakat berada pada kondisi tidak baik.

\section{Pengaruh Rasio Aktivitas Terhadap Kinerja Organisasi Pengelola Zakat}

Hasil penelitian ini menunjukkan bahwa hipotesis $\mathrm{H} 2$ ditolak, artinya rasio aktivitas tidak berpengaruh dan tidak signifikan terhadap kesehatan atau kinerja 
keuangan OPZ. Rasio aktivitas merupakan penilaian aktivitas operasional dana ZIS yang dihimpun oleh OPZ beserta penyalurannya dalam satu tahun yang bersangkutan. Rasio aktivitas juga dipergunakan untuk mengukur efektivitas penggunaan aset sebuah lembaga/organisasi. Namun dalam penelitian ini rasio aktivitas tidak dapat menunjukkan kesehatan atau kinerja keuangan OPZ baik atau buruk.

\section{Pengaruh Rasio Efisiensi Terhadap Kinerja Organisasi Pengelola Zakat}

Hasil penelitian ini menunjukkan bahwa $\mathrm{H}_{3}$ diterima, artinya rasio efisiensi berpengaruh dan signifikan terhadap kesehatan atau kinerja keuangan OPZ. Kemudian jika dilihat pada Tabel 9, nilai koefisien rasio efesiensi menunjukkan angka negatif, berarti rasio efesiensi berpengaruh negatif dan signifikan terhadap kesehatan atau kinerja keuangan OPZ. Rasio efisiensi digunakan untuk menilai efisiensi atas beban operasional OPZ dalam kegiatan penghimpunan dan penyaluran dana ZIS. Jadi semakin efisien OPZ dalam melakukan penghimpunan dana maka semakin baik dalam tata kelola OPZ tersebut. Dalam penelitian ini rasio efisiensi dapat menunjukkan kesehatan atau kinerja keuangan OPZ baik atau buruk.

\section{Pengaruh Rasio Amil Terhadap Kinerja Organisasi Pengelola Zakat}

Hasil penelitian ini menunjukkan bahwa $\mathrm{H}_{4}$ ditolak, artinya rasio dana amil tidak berpengaruh dan tidak signifikan terhadap kesehatan atau kinerja keuangan OPZ. Rasio dana amil digunakan untuk melakukan penilaian efektivitas penggunaan dana amil dalam kegiatan penghimpunan dan penyaluran dana ZIS. Namun dalam penelitian ini rasio dana amil tidak dapat menunjukkan kesehatan atau kinerja keuangan OPZ baik atau buruk.

\section{Pengaruh Rasio Likuiditas Terhadap Kinerja Organisasi Pengelola Zakat}

Hasil penelitian ini menunjukkan bahwa $\mathrm{H}_{5}$ ditolak, artinya rasio likuiditas tidak berpengaruh dan tidak signifikan terhadap kesehatan atau kinerja keuangan OPZ. Rasio likuiditas dihitung untuk mengetahui OPZ dapat membayar hutang jangka pendeknya. Pengukuran rasio likuiditas ini difungsikan untuk mengetahui dana yang mengendap yang belum tersalurkan, dan juga untuk mengetahui kemampuan OPZ menyalurkan dana ZIS kepada yang berhak menerima. Namun dalam penelitian ini rasio likuiditas tidak dapat menunjukkan kesehatan atau kinerja keuangan OPZ baik atau buruk.

\section{Pengaruh Rasio Pertumbuhan Terhadap Kinerja Organisasi Pengelola Zakat}

Hasil penelitian ini menunjukkan bahwa $\mathrm{H}_{6}$ ditolak, artinya rasio pertumbuhan tidak berpengaruh dan tidak signifikan terhadap kesehatan atau kinerja keuangan OPZ. Rasio pertumbuhan ini memperlihatkan kenaikan penghimpunan dana ZIS OPZ dari tahun-tahun sebelumnya. Namun dalam penelitian ini rasio pertumbuhan tidak dapat menunjukkan kesehatan atau kinerja keuangan OPZ baik atau buruk.

Puskasbaznas sebagai pusat rujukan OPZ di Indonesia harusnya dapat lebih tegas dalam melakukan pengendalian dan monitoring semua OPZ tanpa kecuali dalam mempertanggungjawabkan dan mempublikasikan dana yang dihimpun dari Muzaki. Disamping itu untuk mempermudah stakeholder yang 
membutuhkan informasi setiap OPZ, hendaknya Puskasbaznas melakukan penyamaan akun-akun yang terdapat dalam laporan keuangan semua OPZ. Mengingat OPZ merupakan organisasi nirlaba yang menuntut etika/moral/atittude pengelola lembaga zakat, sebaiknya ukuran interpretasi penilaian ratio likuiditas dan pertumbuhan di atas $100 \%$ untuk penilaian tidak baik perlu dilakukan kajian lebih lanjut oleh Puskasbaznas.

\section{KESIMPULAN}

Hasil penelitian menemukan bahwa ternyata laporan keuangan dari lima OPZ menunjukkan kesehatan atau kinerja keuangan masuk kategori penilaian cukup baik. Kemudian rasio aktivitas, amil, likuiditas, dan pertumbuhan tidak berpengaruh terhadap kinerja atau kesehatan keuangan OPZ. Sedangkan rasio efisiensi berpengaruh negatif dan signifikan terhadap kinerja atau kesehatan keuangan OPZ. Kemudian secara simultan rasio aktivitas, efisiensi, amil, likuiditas, dan pertumbuhan berpengaruh signifikan terhadap kinerja atau kesehatan keuangan OPZ dengan besar pengaruhnya adalah 74,9\%, sedangkan sisanya $25,1 \%$ dipengaruhi oleh faktor lain.

Penelitian ini mampu mendeteksi organisai nirlaba yang tidak bertujuan untuk mendapatkan keuntungan. Keterbatasan yang didapatkan selama penelitian adalah laporan pertanggung jawaban OPZ banyak yang tidak dipublikasikan sehingga para stakeholder banyak yang tidak bisa mengakses baik untuk penelitian maupun sebagai bentuk pertanggungjawaban pengelolaan dana, Disamping itu akun dalam laporan keuangan OPZ berbeda-beda, sehingga menyulitkan dalam membandingkan laporan keuangan antar OPZ.

Penelitian selanjutnya diharapkan mengkaji faktor lain selain rasio yang telah diteliti karena masih ada ruang sebesar $25,1 \%$. Kemudian bagi BAZNAS diharapkan mampu meningkatkan pengawasan terhadap OPZ di Indonesia dan hendaknya bersikap tegas agar setiap OPZ dapat mempublikasikan dan menyamakan akun di laporan keuangannya sebagai bentuk transparansi dan pertanggungjawaban terhadap stakeholder.

\section{DAFTAR PUSTAKA}

Abubakar, Imam Taqiuddin. 1993. Kifayatul Akhyar Fii Halli Ghayatil Ikhtishar. Surabaya: Bina Iman.

Ainun, Basyiro, Lusiana Handayani, and M. Yasir Fahmi. 2020. "Analisis Aktivitas Amil Pada Organisasi Pengelola Zakat." Jurnal INTEKNA: Informasi Teknik dan Niaga 20 (2): 100-110. https://ejurnal.poliban.ac.id/index.php/intekna/article/view/1017.

Al Azhar. 2020. Laporan Keuangan Lembaga Amil Zakat Al Azhar Tahun 20152018. Diakses 14 Februari 2020 dari website lazalazhar.org.

Aldi, Rochmat. 2016. Analisis Statistik Ekonomi Dan Bisnis Dengan SPSS. Ponorogo: CV. Wade Group.

Arikunto, Suharsimi. 2013. Prosedur Penelitian Suatu Pendekatan Praktek. Jakarta: Rineka Cipta. 
Bamus BNI. 2020. Laporan Keuangan Yayasan Baitulmal Ummat Islam Bank Negara Indonesia (BAMUIS BNI) Tahun 2015-2018. Diakses 19 Februari 2020 dari website bamuisbni.or.id.

Baznas. 2019. Laporan Keuangan Badan Amil Zakat Nasional (BAZNAS) Tahun 2015-2018. Diakses 28 September 2019 dari website: baznas.go.id.

CPAA. 2014. A Guide to Understanding The Financial Reports of Not For Profit Entities. Diakses dari website: cpaaustralia.com.au.

Harto, Prayogo P., Vivi Sufi Anggraeni, and Ainur Bayinah. 2018. "Komparasi Kinerja Keuangan Lembaga Amil Zakat." JAKIS: Jurnal Akuntansi dan Keuangan Islam 6 (1): 19-33. https://doi.org/10.35836/jakis.v6i1.7.

IAI. 2008. Akuntansi Zakat Dan Infaq/Sedekah PSAK 109. Jakarta: Divisi Penerbitan IAI.

IAI. 2010. Pelaporan Entitas Nirlaba PSAK 45 Edisi Revisi. Jakarta: Divisi Penerbitan IAI.

Kemenag RI. 2011. Petunjuk Pelaksanaan Zakat. Dirjen Bimbingan Masyarakat Islam. Jakarta: Direktorat Pemberdayaan Zakat.

Lestari, Alfi. 2015. "Efisiensi Kinerja Keuangan Badan Amil Zakat Daerah (BAZDA): Pendekatan Data Envelopment Analysis (DEA)." Jurnal Ekonomi \& Studi Pembangunan (JESP) 16 (2): 177-187. https://journal.umy.ac.id/index.php/esp/article/view/1288.

Lubis, Deni, Dedi Budiman Hakim, and Yunita Hermawati Putri. 2018. "Mengukur Kinerja Pengelolaan Zakat Di Badan Amil Zakat Nasional (BAZNAS). JEBI: Jurnal Ekonomi Dan Bisnis Islam 3 (1): 1-16. http://journal.febi.uinib.ac.id/index.php/jebi/article/view/141.

Parisi, Salman Al. 2017. "Tingkat Efisiensi Dan Produktivitas Lembaga Zakat Di Indonesia." Esensi: Jurnal Bisnis dan Manajemen 7 (1): 63-72. http://dx.doi.org/10.15408/ess.v7i1.3687.

Prayogi, Akbar. 2019. Analisis Kinerja Baznas Kota Tangerang Selatan Dengan Pendekatan Indeks Zakat Nasional. Skripsi Fakultas Ekonomi dan Bisnis Universitas Islam Negeri Syarif Hidayatullah Jakarta. https://repository.uinjkt.ac.id/dspace/handle/123456789/46109.

Puskasbaznas. 2019. "Rasio Keuangan OPZ." Jakarta: Puskasbaznas.

RZI. 2020. Laporan Keuangan Rumah Zakat Indonesia Tahun 2015-2018. Diakses 18 Januari 2020 dari website: rumahzakat.org.

Anwar, M. Sofian, Itang Itang, and Havid Risyanto. 2019. "Analisis Efisiensi Lembaga Pengelola Zakat (LPZ) Dalam Mengelola Potensi Zakat Di Indonesia." Tazkiya: Jurnal Keislaman, Kemasyarakatan, \& Kebudayaan 20 145-180. http://jurnal.uinbanten.ac.id/index.php/tazkiya/article/view/2370.

Umar, Husein. 2014. Metode Penelitian Untuk Skripsi Dan Tesis. Jakarta: Raja Grafindo Persada.

YYM. 2020. Laporan Keuangan Yatim Mandiri Tahun 2015-2018. Diakses 14 Februari 2020 dari website: www.yatimmandiri.org. 